\title{
IMPACTS OF SNOWMELT AND CLIMATE CHANGE ON HIMALAYAN RIVERS: THE CASE OF DATA-SCARCE DUDHKOSHI RIVER IN EASTERN NEPAL
}

\author{
Sudeep Pokhrel ${ }^{1,2,}$, Saraswati Thapa ${ }^{2}$ \\ ${ }^{1}$ Nepal Electricity Authority, Kathmandu, Nepal \\ ${ }^{2}$ Department of Civil Engineering, Institute of Engineering, Pulchowk Campus, Lalitpur, Nepal
}

\begin{abstract}
Water from snow-melt is crucial to provide ecosystem services in downstream of the Himalayas. To study the fate of snow hydrology, an integrated modeling system has been developed coupling Statistical Downscaling Model (SDSM) outputs with Snowmelt Runoff Model (SRM) in the Dudhkoshi Basin, Nepal. The SRM model is well-calibrated in 2011 and validated in 2012 and 2014 using MODIS satellite data. The annual average observed and simulated discharges for the calibration year are $177.89 \mathrm{~m}^{3} / \mathrm{s}$ and $181.47 \mathrm{~m}^{3} / \mathrm{s}$ respectively. To assess future climate projections for the periods 2020s, 2050s, and 2080s, the SDSM model is used for downscaling precipitation, maximum temperature, and minimum temperature from the Canadian GCM model (CanESM2) under three different scenarios RCP2.6, RCP4.5 and RCP8.5. All considered scenarios are significant in predicting increasing trends of maximumminimum temperature and precipitation and the storehouse of freshwater in the mountains is expected to deplete rapidly if global warming continues.
\end{abstract}

Keywords - snowmelt, river discharge, climate change, data-scarce basin, Dudhkoshi River

\section{INTRODUCTION}

The Himalayas have the largest concentration of densely accumulated snow and ice outside the Arctic and Antarctica and these are also known as the 'Water Towers of Asia'. The snow in the Hindu Kush Himalayas (HKH) is a huge renewable storehouse of freshwater which releases water gradually during the dry seasons. This storehouse provides some two billion people an essential lifeline through water for food, energy, and ecosystem services (Christopher et al. 2019). The average snow-covered area of the HKH region is about 0.76 million $\mathrm{km} 2$, or $18.2 \%$ of the total land area. From 10 percent to more than 30 percent of the flow in the major river basins originating from the $\mathrm{HKH}$ region is due to annual snowmelt. The HKH region also has abundant glaciers, about $60,000 \mathrm{~km}^{2}$ area of glaciers with a total ice reserve of 6125 $\mathrm{km}^{3}$ (Bajracharaya and Shrestha 2011; IPCC 2008) and it provides about 86 million cubic meters of water annually (Rao et al., 2008). Over the past few decades, the rise in temperature due to global warming has boosted the ablation process. Many research have shown that floods in snow-fed rivers are often associated with snowmelt. Global warming plays a significant role in fluctuating river discharge, the resultant of monsoon rainfall and excess snowmelt cause heavy floods during the wet seasons whereas, the river can have small to no discharge during dry seasons causing water stresses. Hence, the quantification of water release from snowmelt in the mountains is very crucial for water resources management in the downstream.

Hydrological models are the mathematical analogs that aid in understanding, predicting, and managing water resources. Many models are developed to study the river hydrology, however, they don't perform well in the mountainous catchment where snow is the major component. The quantification of snow discharge is usually difficult due to the complexity of processes involved in snowmelt and runoff depiction (Kang, 2005). Also, many of these models are sensitive to precipitation, and the precipitation data obtained from high altitudes may be erroneous or may be collected inadequately. The Snowmelt Runoff Model (SRM) based on the degree-day approach is widely accepted in the study of snow hydrology due to its simplicity and accuracy in mountainous basins where meteorological and hydrological data are scarce. The model can be applied to basins of any size due to its capability of handling remote-sensing data of the cryosphere. Being less sensitive to precipitation and more sensitive to temperature and snow-covered area (SCA), many researchers prefer this model in snow-fed river systems. This model is designed to simulate and forecast the daily discharge in mountainous river basins and was also tested by the World Meteorological Organization for snowmelt runoff simulations and forecasted real-time runoff (Martinec et al., 2008). Previous studies have employed this model in the Hunza River 


\section{International Journal of Engineering Applied Sciences and Technology, 2021 \\ Vol. 5, Issue 12, ISSN No. 2455-2143, Pages 10-22 \\ Published Online April 2021 in IJEAST (http://www.ijeast.com)}

basin, Karakoram (Tahir et al., 2011), Kaidu Watershed, northeast China (Ma et. al, 2013), Budhi Gandaki River Basin (Sharma et al., 2020) and Tamor River Basin in the eastern Nepalese Himalaya (Pandey \& Brown, 2010) for the snowmelt runoff simulation.

Climate change is causing adverse impacts on the hydrological cycle changing precipitation and temperature patterns. A great deal of research has been conducted both on a global and regional scale to study the effects of climate change. Global warming will likely to rise to $1.5{ }^{\circ} \mathrm{C}$ above pre-industrial levels between 2030 and 2052 if warming continues at the current rate (IPCC, 2018). From 1901 to 2014, the annual mean air temperature in the $\mathrm{HKH}$ increased at the rate of about $0.1^{\circ} \mathrm{C}$ per decade, where the warming over the last 50 years has been about $0.2^{\circ} \mathrm{C}$ per decade. Shortly in the future (2036$2065)$, this region is expected to warm by $1.7^{\circ} \mathrm{C}$ to $2.4^{\circ} \mathrm{C}$ for $\mathrm{RCP} 4.5$ and $2.3^{\circ} \mathrm{C}$ to $3.2^{\circ} \mathrm{C}$ for $\mathrm{RCP} 8.5$ and monsoon precipitation is projected to increase by 4 to $12 \%$ (Krishnan et al, 2019). There are clear indications that variations in hydrological changes have dire consequences on biodiversity, water supplies, agriculture, and hazards and these effects will have considerable impacts on general human wellbeing. Therefore, a regional scale climate change study is essential to assess the impact of climate change on the watershed.

Nowadays, Global Circulation Models (GCMs) are widely used to simulate climate change scenarios. The Global Circulation Model also known as General Circulation Model is a complex mathematical model that represents the physical process in the atmosphere, cryosphere, ocean, and land surface (IPCC, 2013a). In addition to physical climatic processes, there are biogeochemical processes as well which impact the climate, and all these processes are included in a new climate model called Earth System Model (ESM) (Heavens et. al, 2013). The Canadian Earth System Model (CanESM2) is one of this kind which combines the Atmosphere-Ocean General Circulation Model (AOGCM) and the terrestrial carbon cycle based on the Canadian Terrestrial Ecosystem Model (Chylek et al, 2011). The CanESM2 is developed by the Canadian Centre for Climate Modeling and Analysis (CCCma) and is prepared for Coupled Model Intercomparison Project Phase 5 (CMIP5) (Taylor et.al., 2012). It is the contribution of the IPCC Fifth Assessment Report (AR5) and the atmospheric component of CanESM2 is the fourth-generation Canadian atmospheric GCM (CanAM4) which was evolved from the CCCma's third-generation AGCM (CanAM3) (Arora \& Boer, 2014).

The GCMs described above have coarse resolution and don't provide information on scales smaller than a few hundred kilometers. Due to this coarse resolution of GCM outputs, it is necessary to convert GCM outputs at least at the scale of watershed or local scale which is called downscaling. Dynamical downscaling and Statistical downscaling are two types of downscaling methods among them statistical downscaling is widely used and selected in this study because it is computationally cheaper and more versatile. This SDSM model was used in South West Ethiopia by (Molla, 2020) to study the impacts of climate change and to simulate climatic data for streamflow modeling in Quebec (Gagnon et.al, 2005) used the same statistical model.

\section{STUDY AREA}

The Dudhkoshi River Basin occupying $3712 \mathrm{~km}^{2}$ area is one of the major sub-basins of the Koshi River Basin in eastern Nepal (Figure 1). The Koshi basin is the main tributary of the Ganges River and is located between latitude $27^{\circ} 16^{\prime}$ to $28^{\circ} 06^{\prime}$ $\mathrm{N}$ and longitude $86^{\circ} 30^{\prime}$ to $87^{\circ} 02^{\prime} \mathrm{E}$. This basin has a steep topography with elevation ranging from about 455 to $8848 \mathrm{~m}$. The river flows through high elevation (the Himalayas in North) to low land (Indogangetic plains in South). The basin gets intense rainfall during every monsoon season that occurs between June to September. Precipitation in the form of snow is predominant above $5000 \mathrm{~m}$ elevation whereas, rainfall usually occurs below $5000 \mathrm{~m}$. The physiography of the basin ranges from the higher Himalayas above $3000 \mathrm{~m}$ to the lesser Himalaya below $3000 \mathrm{~m}$. Most of the anthropogenic activities like agriculture and urban settlements occur in the lesser Himalayan region.

The annual mean temperature recorded in the station no.1206 in Okhaldhunga at $1720 \mathrm{~m}$ elevation is about $17.5^{\circ} \mathrm{C}$. June and July are the hottest months whereas January and February are the coldest months. The annual mean precipitation is about $2000 \mathrm{~mm}$, the highest in July and August months and the lowest in November and December. The Northern part of the basin is usually covered with snow. The maximum and minimum snow coverage is $58 \%$ and $11 \%$ shown by the MODIS satellite between 2010 and 2014. Among seven subbasins in the Koshi basin, the Dudkoshi sub-basin has the highest numbers of glaciers (within Nepal); about 287 numbers of glaciers occupying $393 \mathrm{~km}^{2}$ area (Khadka et al., 2015). The annual average discharge recorded in the outlet 'Rabuwa Bazar station' is about $200 \mathrm{~m}^{3} / \mathrm{s}$. The maximum discharge is recorded in August and the minimum in March.

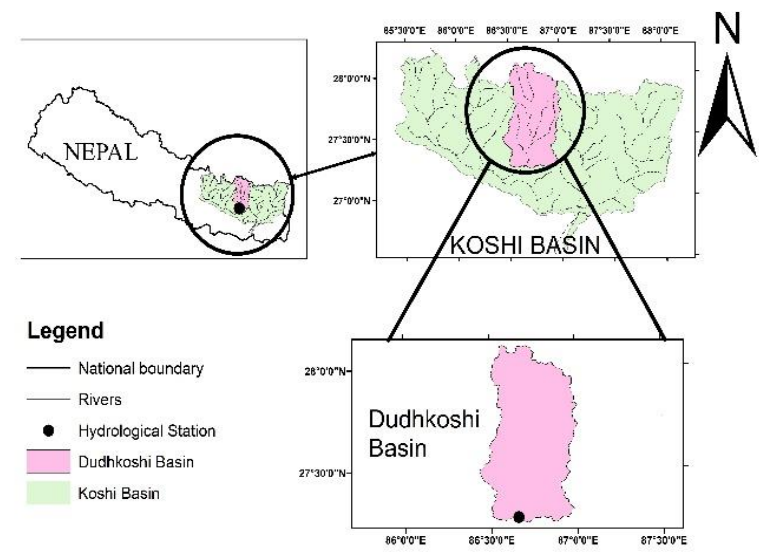

Fig. 1. Location of Study Area 


\section{International Journal of Engineering Applied Sciences and Technology, 2021 \\ Vol. 5, Issue 12, ISSN No. 2455-2143, Pages 10-22 \\ Published Online April 2021 in IJEAST (http://www.ijeast.com)}

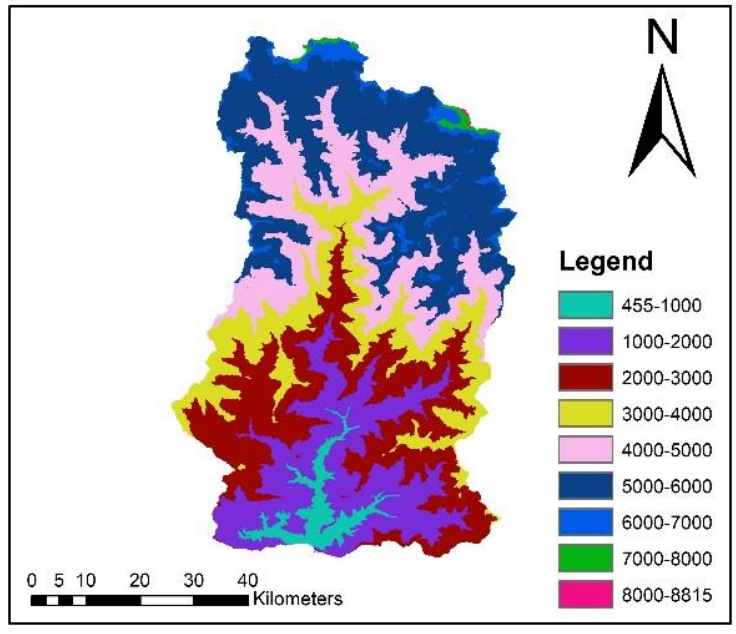

Fig. 2. DEM and reclassification of study area.

\section{METHODOLOGY}

\section{A. Data Collection}

\section{Temperature}

Air temperature is one of the important components of the mountain climate in the study of snow hydrology. It determines whether the precipitation is in the form of snowfall or rainfall. In the SRM model, individual maximum and minimum temperature or the average of the maximum and minimum air temperature can be adopted and the latter was selected in this study. The calculated average temperature was then extrapolated to different elevation zones to compute zonal degree-days using temperature adjustment value $(\Delta \mathrm{T})$ shown in equation 1 .

$$
\Delta T=\gamma\left(h_{s t}-h^{\prime}\right) \times \frac{1}{100}
$$

where, $\gamma$ is temperature lapse rate $\left[{ }^{\circ} \mathrm{C}\right.$ per 100]; $h_{s t}$ is altitude of temperature station (m); and $h$ " is the hypsometric mean elevation of a zone (m).

Because of the limited numbers of meteorological stations available in mountainous regions, data from only one station, station no 1206 Okhaldhunga located at $1720 \mathrm{~m}$ masl, was used in both SRM and SDSM models. To extrapolate zonal degreedays in respective hypsometric elevation zones, the monthly lapse rate evaluated by (Kattel et al., 2012).

Table 1. Temperature lapse rate (Kattel et al., 2012)

\begin{tabular}{|l|l|}
\hline Months & ${ }^{\circ} \mathrm{C} / \mathrm{km}$ \\
\hline Jan & 4.3 \\
\hline Feb & 5 \\
\hline Mar & 5.5 \\
\hline April & 6.1 \\
\hline May & 6 \\
\hline Jun & 5.4 \\
\hline
\end{tabular}

\begin{tabular}{|l|l|}
\hline Months & ${ }^{\circ} \mathrm{C} / \mathrm{km}$ \\
\hline July & 4.7 \\
\hline Aug & 4.8 \\
\hline Sept & 5 \\
\hline Oct & 5.4 \\
\hline Nov & 5.1 \\
\hline Dec & 4.5 \\
\hline
\end{tabular}

\section{Precipitation}

When the elevation range in the river basin is considerable, the precipitation input may be underestimated when only low altitude precipitation stations are used. It is recommended to extrapolate precipitation data to the hypsometric altitudes by an altitude gradient such as $2 \%$ or $3 \%$ per $100 \mathrm{~m}$ from low altitude precipitation stations so that the data better describes the hydrological properties of the basin. Department of Hydrology and Meteorology (DHM) Nepal, has established rain gauges only in lower altitudes around $2000 \mathrm{~m}$ elevation, so only available lower altitudes rain gauge stations were used to calculate the altitude gradient, and the list of rain gauge stations is illustrated in Table 2.

Table 2 List of meteorological stations used to calculate the altitude gradient

\begin{tabular}{|l|l|l|l|l|}
\hline SN & Station Name & $\begin{array}{l}\text { Index } \\
\text { No. }\end{array}$ & Location & $\begin{array}{l}\text { Elevation } \\
(\mathrm{m})\end{array}$ \\
\hline 1 & Chaurikharka & 1202 & Solukhambu & 2619 \\
\hline 2 & Pakarnas & 1203 & Solukhambu & 1982 \\
\hline 3 & Aisealukharka & 1204 & Khotang & 2143 \\
\hline 4 & $\begin{array}{l}\text { Mane } \\
\text { Bhanjang }\end{array}$ & 1207 & Okhaldhunga & 1576 \\
\hline 5 & Diktel & 1222 & Khotang & 1623 \\
\hline
\end{tabular}

The graph of a linear function shown in Figure 3 was plotted to calculate the gradient and the calculated value was $2.3 \%$ per $100 \mathrm{~m}$. The average precipitation of five rain gauges, calculated using the Thiessen polygon method, was extrapolated to hypsometric altitudes using this calculated gradient and these same five rain gauges were selected in the downscaling of precipitation data for the climate change study.

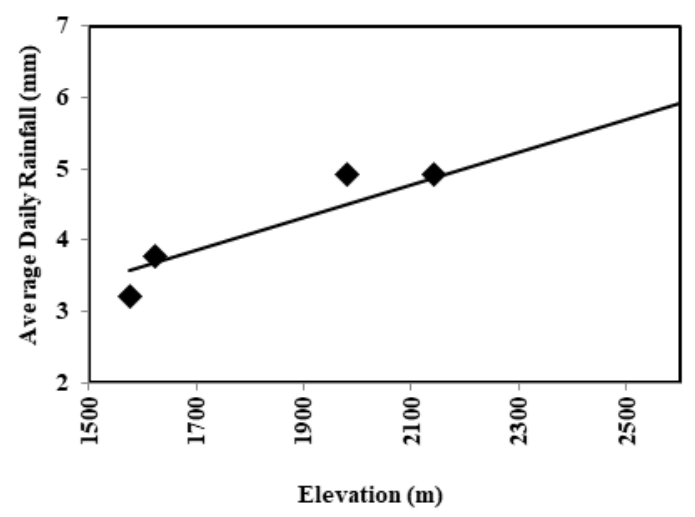

Fig. 3. Rainfall-elevation plot for determination of altitude gradient. 


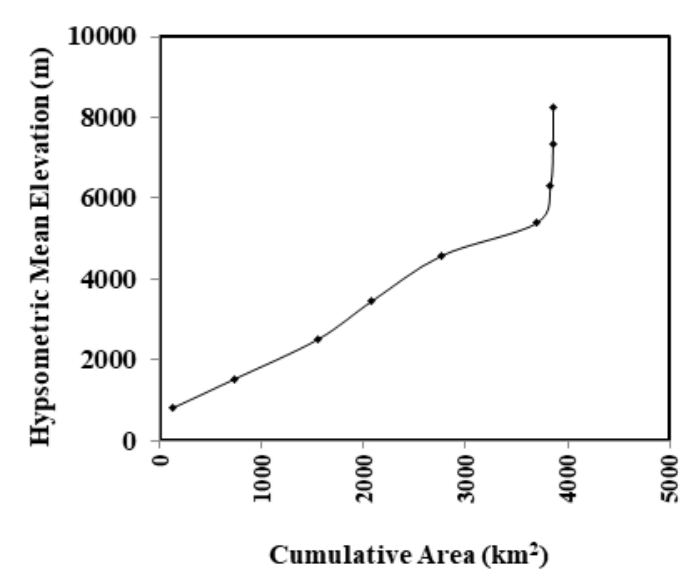

Fig. 4. Area Elevation Curve

\section{Discharge}

Discharge data measured daily for Dudhkoshi River at Rabuwa Bazar station $\left(27.16^{\circ}\right.$ latitude and $86.66^{\circ}$ longitude at $460 \mathrm{~m}$ elevation) was used for calibration, validation, and climate change study purposes. The hydrograph plotted shows the discharge mostly concentrates from June to September, coinciding with the summer monsoon period whereas, the lowest flow is in dry seasons from January to April.

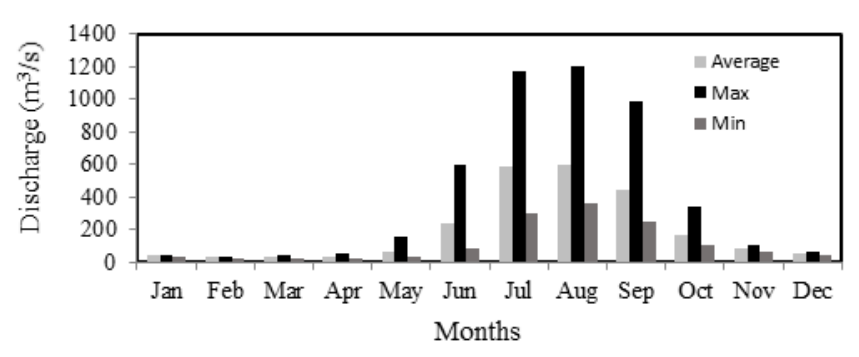

Fig. 5.Monthly Discharge of Dudhkoshi River

\section{B. Snowmelt Runoff (SRM)}

The Snowmelt Runoff Model (SRM or Martinec-Rango Model) is a degree-day model designed to simulate and forecast daily streamflow in mountainous basins where snowmelt is predominant. More recently, this model has been used to evaluate the effect of climate change on seasonal snow cover and runoff dynamics.

The whole basin can be divided into several elevation zones, and it requires daily temperature, precipitation, and SCA as input variables for each zone. The SRM calculates water quantity from snowmelt and rainfall, superimposes that runoff on the calculated recession flow, and transforms into daily discharge using the following equation;

$Q_{n+1}=\left[C_{s n} \alpha\left(T_{n}+\Delta T_{n}\right) S_{n}+C_{R n} P_{n}\right] A \frac{10000}{86400}\left(1-k_{n+1}\right)+Q_{n} k_{n+1}=$
Where, $\mathrm{Q}$ is average discharge $\left[\mathrm{m}^{3} \mathrm{~s}^{-1}\right] ; \mathrm{C}_{\mathrm{S}}$ and $\mathrm{C}_{\mathrm{R}}$ are runoff coefficients for snowmelt and rain respectively $\left[\mathrm{cm} \mathrm{cm}^{-1}\right] ; \alpha$ is degree-day factor $\left[\mathrm{cm}^{0} \mathrm{C}^{-1} \mathrm{~d}^{-1}\right]$ indicating the snowmelt depth from one degree-day, $\mathrm{T}$ is the number of degree-days $\left[{ }^{\circ} \mathrm{C} \mathrm{d}\right.$; $\Delta \mathrm{T}$ is the adjustment by temperature lapse rate when extrapolating the temperature from the station to the average hypsometric elevation of the basin or zone $\left[{ }^{\circ} \mathrm{C} \mathrm{d}\right] ; \mathrm{S}$ is the ratio of SCA to the total area of the basin or zone; $\mathrm{P}$ is precipitation contribution to runoff $[\mathrm{cm}] ; \mathrm{A}$ is an area of the basin or zone $\left[\mathrm{km}^{2}\right] ; \mathrm{k}$ is recession coefficient representing the decline in discharge during a period without snowmelt or rainfall; $n$ is a sequence of days during the discharge computation period; and $10000 / 86400$ is a conversion from cm.km² $\mathrm{d}^{-1}$ to $\mathrm{m}^{3} \mathrm{~s}^{-1}$ (Martinec et al., 2008). The equation is developed for a lag time of 18 hours between the daily temperature cycle and the resulting discharge cycle. In this case, the number of degreedays measured on the nth day corresponds to discharge on the $\mathrm{n}+1$ day.

\section{Basin area and elevation distribution}

It requires a Digital Elevation Model (DEM) to calculate basin area and its elevation distribution. Therefore, the DEM was downloaded from SRTM DEM with a resolution of $30 \times 30 \mathrm{~m}$ shown in Figures 1 and 2. The Dudhkoshi Basin has the elevation distribution from 455 to $8848 \mathrm{~m}$. Due to its wide elevation difference and to describe the physical environment more discretely, the basin was divided into nine elevation zones with an elevation difference of $1000 \mathrm{~m}$ in each zone. The DEM was processed with the spatial analysis capabilities provided in Geographical Information System (GIS) to calculate the area-elevation curve and zonal mean hypsometric elevation levels. Hypsometric elevations are those elevations to which both base station temperatures and precipitation are extrapolated and these extrapolated data represent zonal degree days and zonal precipitation of each zone. The basin area and its elevation distribution are shown in Table 3.

Table 3. Elevation zone, elevation range, hypsometric mean elevation, and zonal area of Dudhkoshi River basin

\begin{tabular}{|l|l|l|l|}
\hline Zone & $\begin{array}{l}\text { Elevation } \\
\text { range (masl) }\end{array}$ & $\begin{array}{l}\text { Zonal } \\
\text { Area } \\
(\mathrm{km} 2)\end{array}$ & $\begin{array}{l}\text { Hypsometric } \\
\text { Mean Elevation } \\
(\mathrm{masl})\end{array}$ \\
\hline 1 & $455-1000$ & 122.51 & 803.79 \\
\hline 2 & $1000-2000$ & 619.18 & 1535.16 \\
\hline 3 & $2000-3000$ & 808.16 & 2506.70 \\
\hline 4 & $3000-4000$ & 531.53 & 3455.47 \\
\hline 5 & $4000-5000$ & 685.46 & 4579 \\
\hline 6 & $5000-6000$ & 931.47 & 5388.3 \\
\hline 7 & $6000-7000$ & 134.9 & 6325.34 \\
\hline 8 & $7000-8000$ & 22.19 & 7338.67 \\
\hline 9 & $8000-8815$ & 1.18 & 8228.25 \\
\hline
\end{tabular}




\section{International Journal of Engineering Applied Sciences and Technology, 2021 \\ Vol. 5, Issue 12, ISSN No. 2455-2143, Pages 10-22 \\ Published Online April 2021 in IJEAST (http://www.ijeast.com)}

\section{Snow Cover}

The snow-covered area (SCA) was obtained from MODIS satellite images which employ the advantage of the fact that snow reflectance is high in the visible $(0.5-0.7 \mu \mathrm{m})$ wavelengths and has low reflectance in the shortwave infrared $(1-4 \mu \mathrm{m})$ wavelengths. This algorithm is based on the normalized difference index (NDSI) which uses at-satellite reflectances in MODIS bands $4(0.545-0.565 \mu \mathrm{m})$ and $6(1.628-1.652 \mu \mathrm{m})$ (Hall et. al, 2002). Snow cover pixels and non-snow pixels are separated using equation (3).

$$
\text { NDSI }=\frac{\text { MODIS }_{B 4}-\text { MODIS }_{B 6}}{\text { MODIS }_{B 4}+\text { MODIS }_{B 6}}
$$

MODIS snow cover products were obtained from the National Snow and Ice Data Centre (NSIDC; https://modis.gsfc.nasa.gov/data/) (Hall et al., 2006). The MOD10A2 products contain a maximum 8-day snow cover at a $500 \mathrm{~m}$ resolution and are derived from the MOD10A1 daily snow cover product. These images contain maximum snow extent during the eight-day periods plus other values. Cells with snow on any day during the period are mapped as snow but clouds are reported only if all eight days are obscured by clouds. The 8-day products were chosen to minimize cloud obscuration, which was common in this region during the summer season. The MODIS products were acquired from the tile number h25v06, horizontal 25 and vertical 06, which were then processed in GIS software to extract snow cover, and respective snow areas were distributed to each hypsometric elevation zones. In 2011, 2012, and 2014 the annual average snow cover in the basin was found to be $22.8 \%, 19.5 \%$, and $26.32 \%$ of the total catchment area respectively.
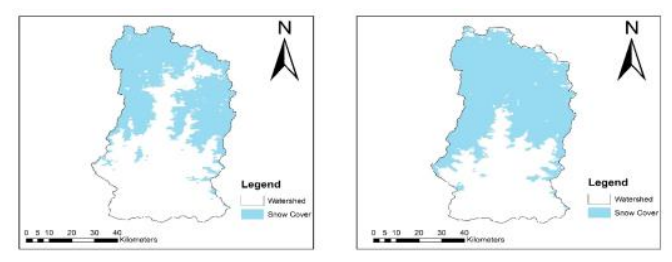

Fig. 6. Snow Cover area in the Basin Feb 18, 2014 (left) and Feb 10, 2011 (right).

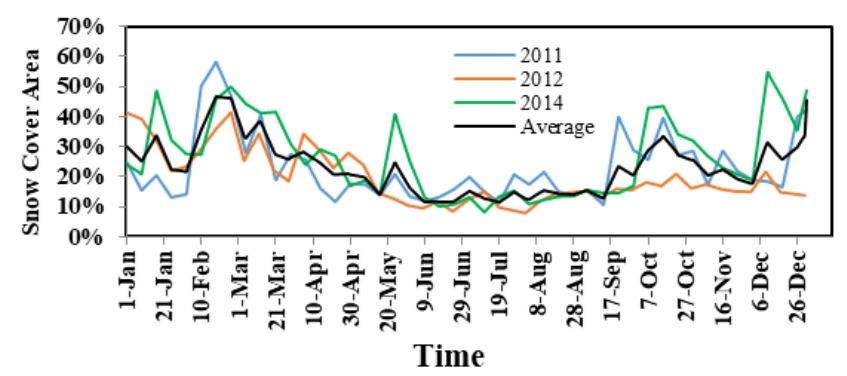

Fig. 7.Snow Cover(\%)

\section{Calibration}

In the calibration of the SRM model, the most critical task is to set model parameters. These parameters can be estimated from field measurements, theoretical or empirical relations. But, due to the lack of adequate field data in this region, the parameters were set using manual calibration based on several runs of the model, literature reviews, and the user manual (Martinec et al., 2008), as parameters estimated from sparse data could be erroneous. The model uses seven different parameters and are described below.

The runoff coefficients $\left(\mathrm{C}_{S}\right.$ and $\left.\mathrm{C}_{\mathrm{R}}\right)$ represent the difference between available water volume and outflow from the basin. On a long-term basis, they correspond to the ratio of runoff to precipitation over a given period. The SRM accepts separate values of runoff coefficient for snow and rainfall because the runoff coefficient is usually different for snowmelt and rainfall (Bhattarai, 2011). The runoff coefficient depends on the character and condition of the soil. The moisture condition of the soil has a direct influence on the infiltration rate which decreases as snowmelt and rainfall continues. In this study, the runoff coefficient of snow was used between 0.3 and 0.6 , and the coefficient of rain was between 0.3 and 0.8 where lower values were used for the cold and dry months and higher for wet months.

The degree-day factor $\alpha\left[\mathrm{cm}^{0} \mathrm{C}^{-1} \mathrm{~d}^{-1}\right]$ converts the number of degree-days $\mathrm{T}\left[{ }^{\circ} \mathrm{C} . \mathrm{d}\right]$ into the daily snowmelt depth, $\mathrm{M}[\mathrm{cm}]$ as shown in equation (4):

\section{$\mathrm{M}=\alpha \cdot \mathrm{T} n(4)$}

Degree-day ratios can be evaluated by comparing degree-day values with the daily decrease of the snow water equivalent which is measured by a radioactive snow gauge, snow pillow, or a snow lysimeter. In the absence of detailed data, the degreeday factor can be obtained from an empirical relation (Martinec, 1960) as shown in equation (5):

$\alpha=1.1 \frac{p_{3}}{P_{W}} \quad \ldots(5)$

where, $\alpha$ is the degree-day factor $\left[\mathrm{cm}^{0} \mathrm{C}^{-1} \mathrm{~d}^{-1}\right] ; \sigma_{\mathrm{s}}$ is density of snow; and $\sigma_{\mathrm{w}}$ is the density of water.

The initial value of degree-days was calculated from the equation (5) and adjusted by the hit and trial method. The minimum value of degree-day factor $0.5 \mathrm{~cm}^{\circ} \mathrm{C}^{-1} \mathrm{day}^{-1}$ was used for lower elevations whereas the maximum of $0.7 \mathrm{~cm}^{\circ} \mathrm{C}^{-1} \mathrm{day}^{-1}$ was used in higher elevations (Table 5).

The recession coefficient is a significant factor of SRM since (1-k) is the portion of the daily rainfall and snow-melt runoff that contribute to daily discharge. The coefficient ' $\mathrm{k}$ ' which governs the decline of discharge during no snowmelt or rainfall, can be obtained using time-series data, dividing the actual stream discharge on day $n+1$ by the actual discharge on day $n$,

$k=\frac{Q_{\mathrm{n}+1}}{Q_{\mathrm{n}}} \ldots(6)$ 
The graph, $\mathrm{Q}_{\mathrm{n}}$ versus $\mathrm{Q}_{\mathrm{n}+1}$ was plotted as shown in Figure 8 and the lower envelope line was considered to indicate the $\mathrm{k}$ values. The value of $\mathrm{k}$ is not constant, but decreases with the increasing Q;

$$
k_{n+1}=x \cdot Q_{n}^{-y} \ldots(7)
$$

where the constants $\mathrm{x}$ and $\mathrm{y}$ can be determined for a given basin using the following equations;

$\log k_{1}=\log x-y \log Q_{1} \ldots(8 a)$
$\log k_{2}=\log x-y \log Q_{2} \ldots(8 b)$

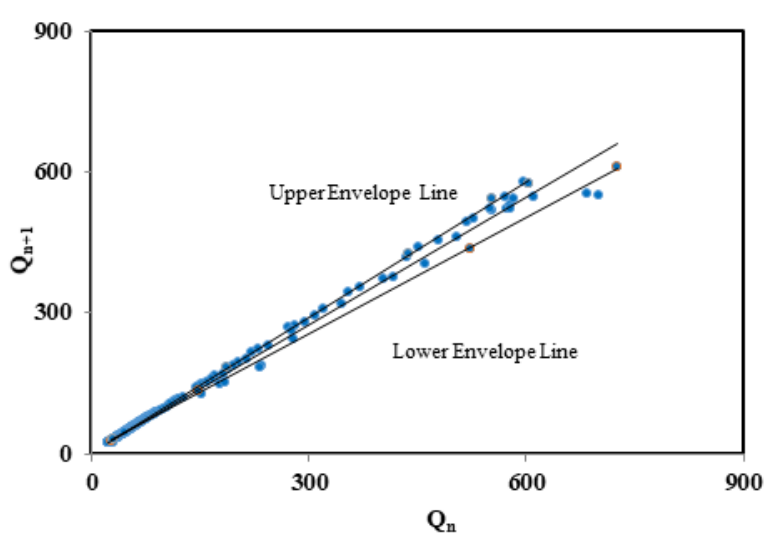

Fig. 8. Recession flow plot

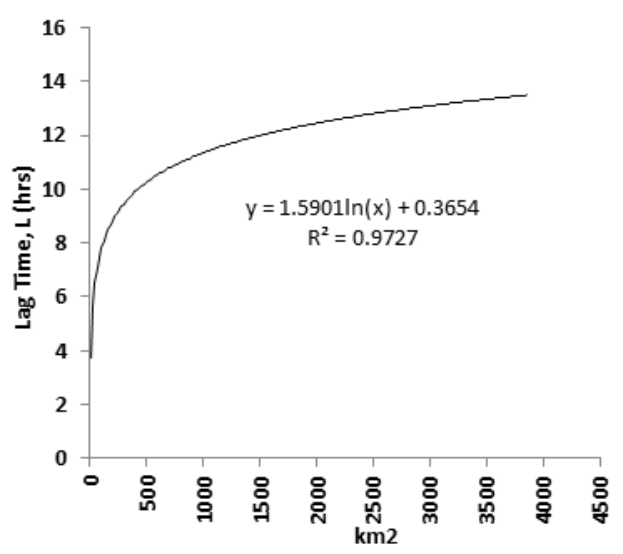

Fig. 9. Regression plot for basin area versus time lag.

Rainfall Contributing Area (RCA) is a parameter used in SRM to determine whether rainfall runoff is added to snowmelt runoff only from snow-free area (option 0) or from the entire basin or zone area (option 1), where option 0 and option 1 are options available in SRM for windows (WinSRM). If option 0 is set in simulation, rainfall-runoff is added to snowmelt runoff only from the snow-free area. If option 1 is set, rainfall-runoff is added to snowmelt runoff from the entire basin or zone area. In this study, below $5000 \mathrm{~m}$, RCA was taken as ' 1 ' indicating runoff due to rainfall is added to snowmelt from the entire basin, and for 5000 to $7000 \mathrm{~m}$ option ' 1 ' was taken only for snowmelt seasons (May to August) but when snow cover becomes ripe in rest of the months ' 0 ' was taken. Above 7000 m elevation, RCA was taken as ' 0 ' for all months because precipitation is in the form of snow only.

The critical temperature is a threshold value used in SRM which determines whether the precipitation is in the form of rain or snow. Critical temperature is usually higher than the freezing point and diminishes to close to $0^{\circ} \mathrm{C}$. Pokhrel et al., (2014) used a critical temperature $0{ }^{\circ} \mathrm{C}$ for the Dudhkoshi basin. Similarly, Khadka et al., (2015) used critical temperature $0{ }^{\circ} \mathrm{C}$ for all zones in the Koshi Basin. Meanwhile, $\mathrm{T}_{\text {CRTT }}$ was taken $1.5^{\circ} \mathrm{C}$ for all zones in this study.

Table 4 Calibrated Parameters for SRM model

\begin{tabular}{|l|c|}
\hline Temperature Lapse Rate $\left({ }^{\circ} \mathrm{C} / 100 \mathrm{~m}\right)$ & $4.3-4.5$ \\
\hline Critical Temperature $\left({ }^{\circ} \mathrm{C}\right)$ & 1.5 \\
\hline Degree Day Factor $\left(\mathrm{cm}^{0} \mathrm{C}-1\right.$ day-1) & $0.5-0.7$ \\
\hline Time Lag (hours) & 13.53 \\
\hline Runoff Coefficient for Rainfall $\left(\mathrm{c}_{\mathrm{R}}\right)$ & $0.3-0.8$ \\
\hline Runoff Coefficient for Snow $\left(\mathrm{c}_{\mathrm{S}}\right)$ & $0.3-0.6$ \\
\hline X- coefficient & $0.968-1.045$ \\
\hline Y-Coefficient & $0.011-0.04$ \\
\hline
\end{tabular}

The time lag in SRM incorporates delay in the amount of time between the streamflow discharge and the rise in temperature (Martinec et al., 1994). The normally used value for the time lag in SRM is 18 hours; however, the time lag can be estimated using historical streamflow data. If these records are not available, the time lag can be estimated according to the size of the basin and by comparison with other similar basins. The time lag versus catchment for this basin was calculated using the regression plot of basin area and the time lag generated for the inter-comparison test (WMO, 1986) as shown in Figure 9. The time lag for the Dudhkoshi basin was $13.53 \mathrm{hrs}$.

\section{Evaluation of Model Performance}

The SRM model can depict a graphical display of the computed hydrograph and the measured runoff, which illustrates whether the simulation is successful or not. For a more objective assessment of how well the simulation is performed, the SRM model uses two well-established accuracy criteria; the coefficient of determination $\mathrm{R}^{2}$, also called the Nash-Sutcliffe coefficient, and the volume difference Dv.

The coefficient of determination is computed as follows:

$R^{2}=1-\frac{\sum_{i=1}^{n}\left(Q_{i}-Q_{i}^{0}\right)^{2}}{\sum_{i=1}^{n}\left(Q_{i}-\bar{Q}\right)^{2}} \cdots(9)$

where, $\mathrm{Q}_{\mathrm{i}}$ is measured daily discharge, $\mathrm{Q}_{\tilde{\mathrm{i}}} \mathrm{i}$ is the simulated daily discharge, $\overline{\mathrm{Q}}$ is the average measured discharge of the given year or snowmelt season and $\mathrm{n}$ is the number of the daily discharge values.

The deviation of the runoff volumes, $D_{v}$, is computed as follows:

$\mathrm{D}_{\mathrm{V}}[\%]=\frac{\mathrm{V}_{\mathrm{R}}-\mathrm{V}_{\mathrm{R}}^{v}}{\mathrm{~V}_{\mathrm{R}}} * 100 \quad \ldots(10)$ 


\section{International Journal of Engineering Applied Sciences and Technology, 2021 \\ Vol. 5, Issue 12, ISSN No. 2455-2143, Pages 10-22 \\ Published Online April 2021 in IJEAST (http://www.ijeast.com)}

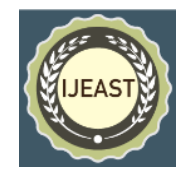

where, $V_{R}$ is the measured yearly or seasonal runoff volume and $\mathrm{V}_{\mathrm{R}}^{\prime}$ is the computed yearly or seasonal runoff volume. The R2 values lie between 0 and 1 where 0 indicates a worst fit and 1 indicates a perfect fit. $D_{V}$ can take any value, the smaller value is the better are the results.

\section{Climate Change Impact Detection}

There are many GCMs available for the climate change study; the selection of GCM depends on its availability and applicability for the study. In this study, the second generation of the Canadian Earth System Model, CanESM2 was selected because only GCM from CanESM2 has provided the predictor variables for RCP scenarios. The predictor variables provide daily information concerning the large-scale state of the global atmosphere, while the predictand describes conditions at the site scale (temperature and precipitation observed at the station). These large-scale predictor variables were obtained from the National Centre for Environment Prediction (NCEP) reanalysis data set and CanESM2 GCM data for the baseline and climate scenarios were downloaded from the Canadian Institute for Climate studies. The predictor variables were provided on a grid box and this grid is uniform along the longitude with a horizontal resolution of $2.8125^{\circ}$ and is nearly uniform along the latitude of roughly $2.8125^{\circ}$. The predictors for the Dudhkoshi Basin was represented by the grid box "BOX 032X 42Y". These CanESM2 outputs were obtained for three different climate scenarios; Representative Concentration Pathway (RCP) 2.6, RCP4.5, and RCP8.5.

The Statistical Downscaling Model (SDSM) was used in this study to downscale the coarse outputs of GCM and project the future climate data. SDSM calculates statistical relation based on multiple linear regression techniques between large-scale predictors and local predictand. The model has four main parts; identification of predictors, model calibration, weather generator, and generation of future series of climate variables.

\section{Quality control and data transformation}

The quality of the observed data has high importance in the regression-based model. The SDSM model has the facility to check the quality of the data and make the transformation as required by the model. Station-based meteorological data may have missing records. The quality control check function identifies such errors before model calibration. The regression technique assumes that the input data are normally distributed. If the data are not normally distributed, in the case of the precipitation variable, the transformation techniques available in the SDSM model are applied to the variables so that the distribution becomes normal. In this study, the precipitation variable was transformed into the fourth root with the conditional process.

\section{Screening of downscaling predictor variables}

The screening of predictors is an important task in all statistical downscaling methods (Feng et. al, 2014). A combination of the correlation matrix, partial correlation, and P-value are generally adopted and the same has been chosen here. All available 26 predictors from NCEP/NCAR reanalysis dataset were screened in each meteorological station to know the highly correlated variables with high partial correlation and lowest $\mathrm{P}$ value at the significance level of 0.05 . These highly correlated variables were selected for the model calibration.

\section{Model Calibration}

Model calibration in SDSM was done using observed station data (Tmax, Tmin, and Precipitation) and screened sets of observed predictors (NCEP/NCAR reanalysis datasets). The SDSM has three different sub-models; monthly, seasonal, and annual, and is composed of two optimizing options; dual simplex and ordinary least squares for the downscaling process. Monthly sub-model and Ordinary least squares optimizing function were selected in this study. The monthly submodel was developed for both temperature and precipitation datasets which derived 12 different regression equations for each dataset. Also, the model can either be specified to an unconditional or conditional process. The unconditional model process assumes that there is a direct link between the predictors and the predictands whereas the conditional model assumes the existence of an intermediate process between them. The model process was set to unconditional for temperature and conditional for precipitation. The available 45 years observed dataset 1961-2005 was divided into two groups for the calibration and validation process. The first 30 years (1961-1990) datasets were allocated for the calibration and the remaining 15 years (1991-2005) were kept for the validation. During calibration, the adjustment in variance inflation and bias correction was done. Variance inflation helps to control the magnitude of variance in downscaled daily weather whereas bias correction compensates the tendency of over and underestimation of the mean conditional process (Wilby \& Dawson, 2007).

\section{Weather Generator and Validation of the SDSM Results}

The Weather Generation tool generates the ensembles of synthetic daily weather data of Tmax, Tmin, and Precipitation for the specified period with the help of regression model weights prepared during calibration and the selected large scale atmospheric predictor variables from NCEP/NCAR reanalysis data. Twenty ensembles of synthetic daily weather data series were generated and the average value of these twenty ensembles provided the output weather data series. Thus obtained output dataset and observed dataset were compared using mathematical relations for the calibration process. After successful calibration, the same process is repeated with the next dataset (1991-2005) for validating the model.

\section{Scenario Generation}

Same as the weather generator function, the scenario generator function also generates the ensembles of synthetic daily 


\section{International Journal of Engineering Applied Sciences and Technology, 2021 \\ Vol. 5, Issue 12, ISSN No. 2455-2143, Pages 10-22 \\ Published Online April 2021 in IJEAST (http://www.ijeast.com)}

weather data series. After successful calibration and validation of the model, the same regression weights used during weather generator operation were used for downscaling the future climatic dataset. But this time, instead of using NCEP/NCAR reanalysis data, the CanESM2 dataset was used as large scale atmospheric predictor variables. Three emission scenarios from the CanESM2 had been chosen; RCP2.6, RCP4.5, and RCP8.5. For each emission scenario, twenty ensembles of synthetic daily time series data were generated for the period 2006-2100, and the mean of these twenty ensembles was used as final daily weather data for three different time frames; 2020s, 2050s, and 2080s.

\section{Statistical Performance Evaluation of the Model}

The performance of the SDSM model was evaluated based on some quantitative statistics; correlation coefficient (r), coefficient of determination $\left(\mathrm{R}^{2}\right)$, root mean square error (RMSE), and Nash-Sutcliffe efficiency (NSE).

Correlation coefficient (r) is the measure of the degree of linear relationship between observed and simulated data. It ranges from -1 to 1 . The higher or lower the value of $r$ from 0 represents the better relationship whereas 0 represents no linear relationship. Mathematically,

$$
r=\frac{\sum_{i=1}^{n}\left(x_{i}-\bar{x}\right)\left(y_{i}-\bar{y}\right)}{\sqrt{\sum_{i=1}^{n}\left(x_{i}-\bar{x}\right)^{2} \cdot \sum_{i=1}^{n}\left(y_{i}-\bar{y}\right)^{2}}}
$$

The coefficient of determination(R2) compares the explained variance of modeled data with the total variance of the observed data and the value ranges from 0 to 1 . The higher the R2 the better is the model performance. Mathematically,

$$
R^{2}=\frac{\sum_{i=1}^{n}\left(y_{i}-\bar{x}\right)^{2}}{\sum_{i=1}^{n}\left(x_{i}-\bar{x}\right)^{2}}
$$

The NSE determines the relative magnitude of variance of residues and measured data. The values below 0 represent unacceptable performance whereas nearer to 1 indicates the best performance. Mathematically,

$$
\mathrm{R}^{2}=1-\frac{\sum_{\mathrm{i}=1}^{\mathrm{n}}\left(\mathrm{x}_{\mathrm{i}}-\mathrm{y}_{\mathrm{i}}\right)^{2}}{\sum_{\mathrm{i}=1}^{\mathrm{n}}\left(\mathrm{x}_{\mathrm{i}}-\mathrm{x}^{2}\right)^{2}}
$$

The RMSE is the index that measures the difference between observed and simulated values. The RMSE value of 0 represents the perfect fit. Mathematically,

$$
\text { RMSE }=\sqrt{\frac{\sum_{i=1}^{n}\left(x_{i}-y_{i}\right)^{2}}{n}}
$$

\section{RESUlt AND Discussions}

\section{SRM Model calibration, validation and Discussions}

The SRM model uses measured discharge, temperature, precipitation, and snow-covered area as input variables and critical temperature $\left(\mathrm{T}_{\mathrm{CRIT}}\right)$, time lag $(\mathrm{L})$, runoff coefficients for snow $\left(C_{S}\right)$, runoff coefficient for rain $\left(C_{R}\right)$, rainfall contributing area (RCA), degree-day factor $(\alpha)$, X-coefficient and $\mathrm{Y}$ coefficient as parameters and these parameters require calibration.

The data for the year 2011 was used for calibration and the data for years 2012 and 2014 were used for validation purposes. The year 2013 was discarded due to incomplete hydrometeorological data. Discharge was well-calibrated for the year 2011 with a coefficient of determination $\left(\mathrm{R}^{2}\right)$ of $80.7 \%$ and the volume difference $\left(\mathrm{D}_{\mathrm{V}}\right)$ of $-2.42 \%$. Similarly, the discharge was well-simulated for the year 2012 with $\mathrm{R}^{2}$ of $82 \%$ and $\mathrm{D}_{\mathrm{V}}$ of $4.3 \%$ and for the year 2014 with $\mathrm{R}^{2}$ of $81.77 \%$ and $\mathrm{D}_{\mathrm{V}}$ of $0.11 \%$. The results of calibration and validation are presented in Figure 10.

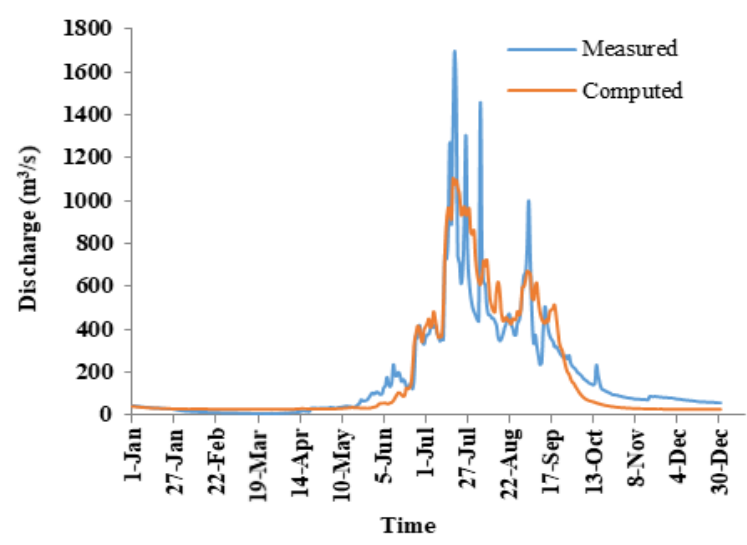

(a)

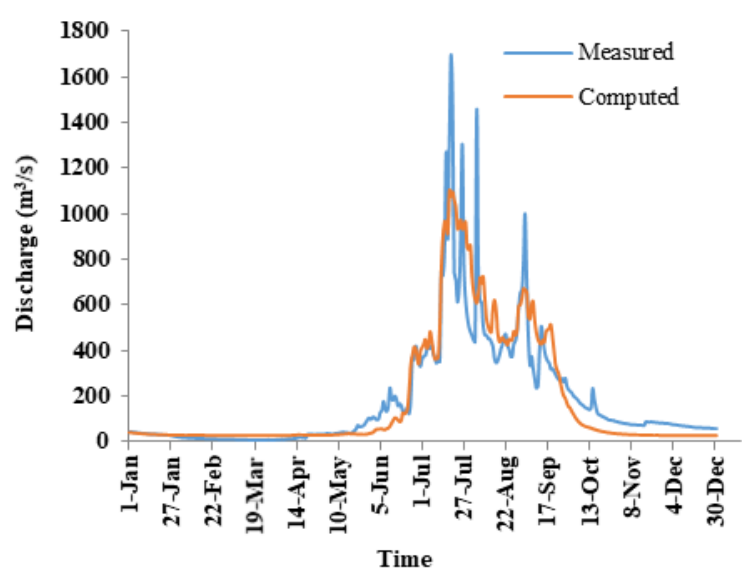

(b) 


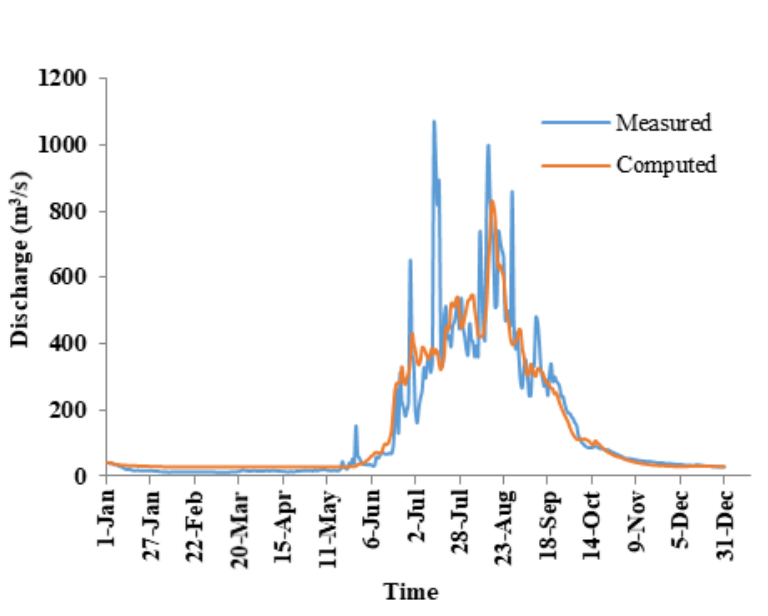

(c)

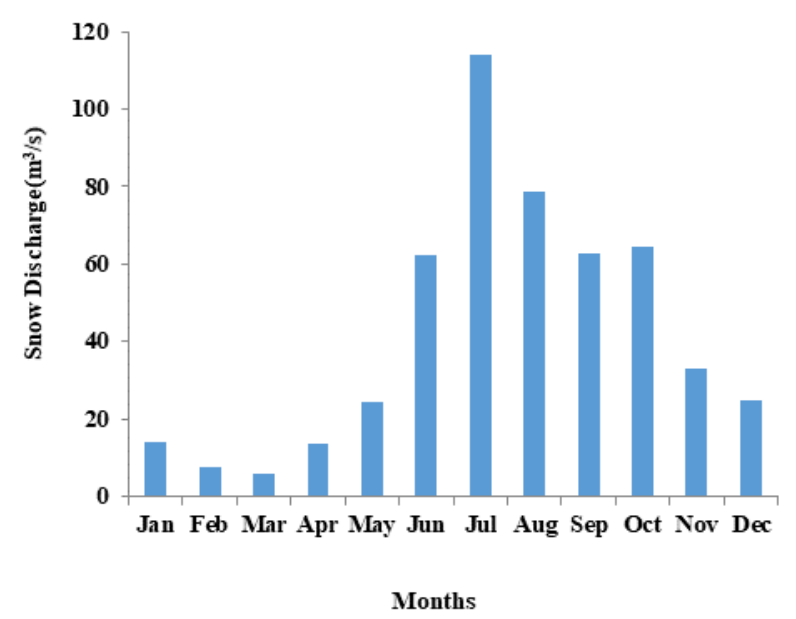

(d)

Fig. 10. a) Calibration for Dudhkoshi River (2011), b) Validation for Dudhkoshi River (2012), c) Validation for Dudhkoshi River (2014), d) average annual snowmelt

The average annual contribution of snowmelt to the streamflow was about $25 \%$ and the average contribution was about $53.75 \%$ of the dry flow in the dry seasons. It can be ascertained that the snowmelt is the major source of the streamflow in this basin; half of the discharge in the dry period and a quarter of annual discharge is due to snowmelt. The results were compared with results from earlier studies. Chhetri (2015) used Energy Budget Model (EBM) to calculate the contribution of snowmelt in the same basin and estimated that the annual snowmelt contribution was $20.83 \%$ and the dry period contribution was $59.03 \%$ of dry flow considering the dry period between March to May. The study conducted by (Nepal et al., 2015) also found that melt runoff, including snowmelt and ice melt from the entire Dudhkoshi catchment, was $24 \%$ and $35 \%$ of the total simulated runoff from GR4JSG and J2000 models, respectively.

During the monsoon season, discharge in the river is much higher due to an increase in temperature and precipitation. In the summer, due to the availability of degree-days, snowmelt runoff is considerable and this has caused the computed and measured runoff to increase. During winter, the discharge is minimum because of low precipitation and few degree-days to melt snow.

Though satisfactory $\mathrm{R}^{2}$ and $\mathrm{D}_{\mathrm{V}}$ have been obtained in the simulation, the peak of measured and simulated discharge has not matched well. Peak discharge values of computed and measured runoff fluctuate directly with runoff coefficients and the location of peak flow is governed by recession coefficients. Some of these parameters were selected through the hit and trial method and some were obtained from literature reviews which may have resulted in a mismatch between peaks. Better simulation results may be obtained from recorded data and laboratory data. Another reason for poor simulation of peak discharge is the unavailability of representative rainfall data in each elevation zone. However, considering the limited data and measurements available in this basin, the performance of the SRM is found to be satisfactory.

\section{Downscaling Results of CanESM2 Outputs}

The predictor variables from NCEP/NCAR reanalysis were chosen to calculate partial correlations and the percentage of variance explained by each predictor-predictand pairs. The final set of predictor variables were selected after analyzing the correlation coefficient, and checking the association of predictors and predictand with scatter plot. The predictors nceppprcgl, nceps500gl, and nceps850gl were more dominant with the precipitation dataset whereas ncepp500gl and nceptempgl had the strongest association with the temperature dataset. From the 45 years of data representing the current climate, the first 30 years (1961-1990) were allocated for calibrating the model, and the remaining 15 years (1991-2005) were used for validating the model. Figures 11 and 12 show the calibration and validation of SDSM downscaling of daily precipitation (only one station among five stations) and daily minimum temperature respectively.

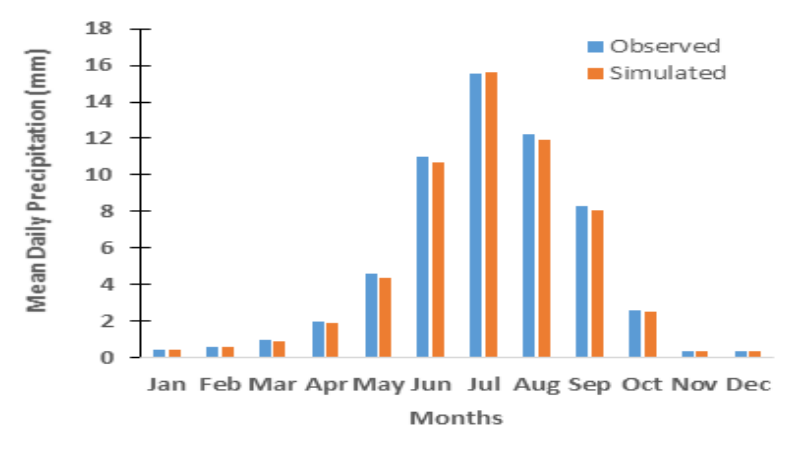

(a) 


\section{International Journal of Engineering Applied Sciences and Technology, 2021 \\ Vol. 5, Issue 12, ISSN No. 2455-2143, Pages 10-22 \\ Published Online April 2021 in IJEAST (http://www.ijeast.com)}

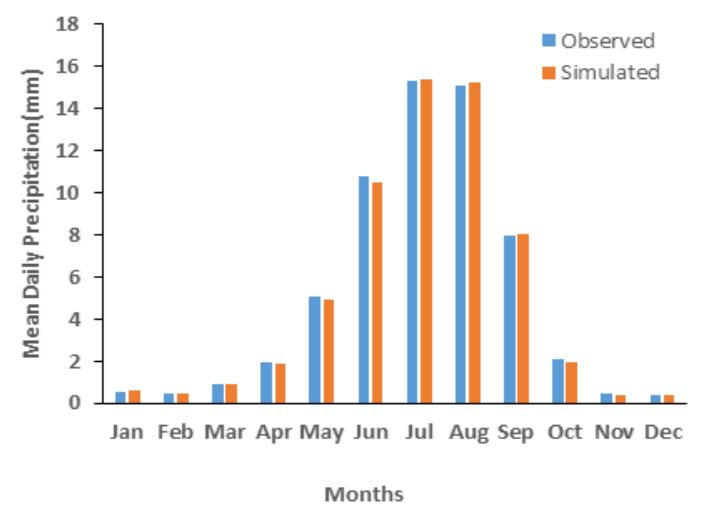

(b)

Fig. 11. a) Calibration b) Validation of SDSM downscaling of daily precipitation at station 1222 .

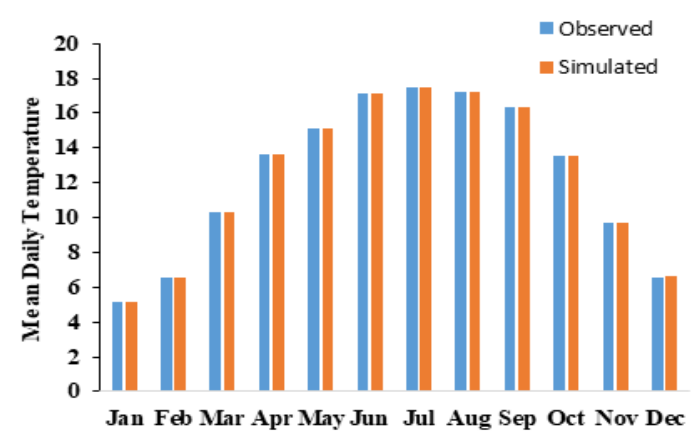

Months

(a)

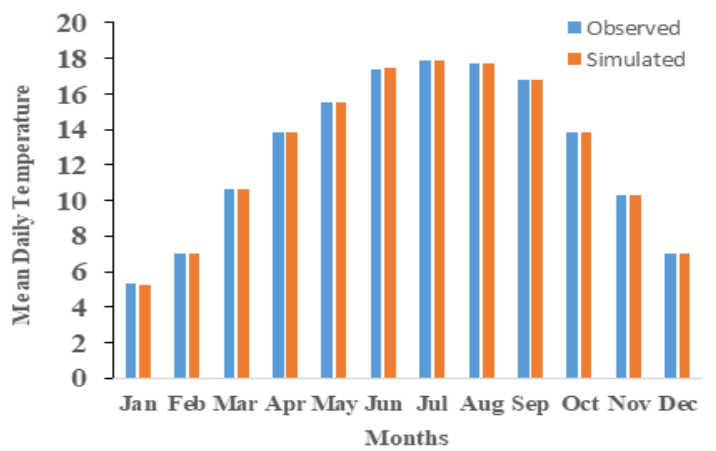

(b)
Fig. 12. a) Calibration b) Validation of SDSM downscaling of daily minimum temperature at station 1206.

The performance of the SDSM model was evaluated based on different statistical methods; RMSE, NSE, r, and $\mathrm{R}^{2}$. The results obtained from these methods showed that the SDSM model performed well for both temperature and precipitation (Table 5). The lower RMSE and higher NSE, $r$ and $R^{2}$ demonstrated the better efficiency of the model.

The final step of analysis was to downscale future precipitation, maximum temperature, and minimum temperature for the scenarios RCP 2.6, RCP 4.5, and RCP 8.5. The calibrated model of each station (five precipitation stations and one temperature station) was used to generate future climate scenarios. The analysis of future climatic variables was done by classifying the future dataset into three time periods; 2011-2040, 2041-2070, and 2071-2100 considered as the 2020s, 2050s, and 2080s respectively. The baseline period for both precipitation and temperature was considered the duration from 1980 to 2009.

Table 5 Statistical evaluation of SDSM performance for calibration and validation with NCEP/NCAR dataset.

\begin{tabular}{|c|c|c|}
\hline & $\begin{array}{c}\text { Calibration } \\
(1961-1990\end{array}$ & $\begin{array}{c}\text { Validation } \\
(1991-2005\end{array}$ \\
\hline RMSE & $0.006-1.77$ & $0.007-0.136$ \\
\hline NSE & $0.93-1$ & $0.97-1$ \\
\hline $\mathrm{r}$ & $0.96-0.99$ & $0.98-0.99$ \\
\hline $\mathrm{R}^{2}$ & $0.932-1$ & $0.976-1$ \\
\hline
\end{tabular}




\section{International Journal of Engineering Applied Sciences and Technology, 2021 \\ Vol. 5, Issue 12, ISSN No. 2455-2143, Pages 10-22 \\ Published Online April 2021 in IJEAST (http://www.ijeast.com)}

The projection of precipitation didn't show consistent increase or decrease trends in the future periods, however, it is projected to increase with regional diversity. The downscaled temperature clearly showed increasing trends in mean annual temperature in all future time horizons. In the 2020s, the average precipitation is likely to increase by $10.5 \%, 6.5 \%$, and $7.8 \%$ in RCP2.6, 4.5, and 8.5 respectively, and the mean temperatures are assumed to increase by $0.7^{\circ} \mathrm{C}, 0.66^{\circ} \mathrm{C}$, and $1.5^{\circ} \mathrm{C}$ under the $\mathrm{RCP} 2.6,4.5$, and 8.5 respectively. In the $2050 \mathrm{~s}$, the average precipitation is likely to increase by $11.4 \%$, $13.3 \%$, and $17.04 \%$ in $\mathrm{RCP} 2.6,4.5$, and 8.5 respectively, and the mean temperatures are assumed to increase by $1.03^{\circ} \mathrm{C}$, $1.5^{\circ} \mathrm{C}$, and $2.14^{\circ} \mathrm{C}$ under the RCP $2.6,4.5$, and 8.5 respectively. And in the 2080s, the average precipitation is likely to increase by $11.9 \%, 16.64 \%$, and $28.47 \%$ in $\mathrm{RCP} 2.6,4.5$, and 8.5 respectively, and the mean temperatures are assumed to increase by $1.26^{\circ} \mathrm{C}, 1.95^{\circ} \mathrm{C}$, and $3.3^{\circ} \mathrm{C}$ under the RCP2.6, 4.5, and 8.5 respectively. For both temperature and precipitation, RCP8.5 is the worst scenario and the immense climatic changes are expected to happen in the 2080s.

\section{Impact of Future Climate Change on Snowmelt Runoff}

The main goal of this study was to examine the impacts of climate change on the run-off of snow-fed rivers. For this, the downscaled future precipitation and temperature from SDSM were used as input variables in the validated SRM model to simulate the runoff for the scenarios RCP2.6, RCP4.5, and RCP8.5 on three-time frames. Figure 13 shows the change in temperature, precipitation, and discharge simulated under three RCPs from the 2020s to the 2080s.

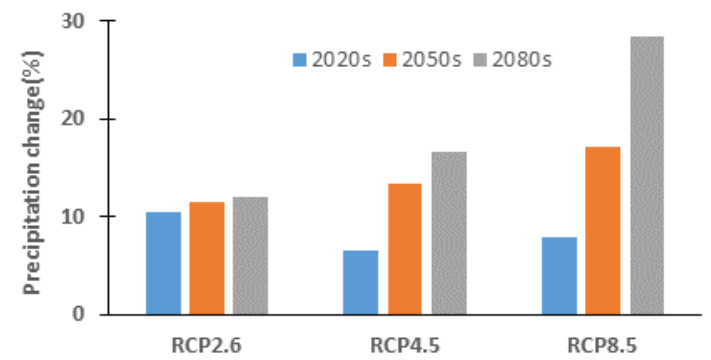

(a)

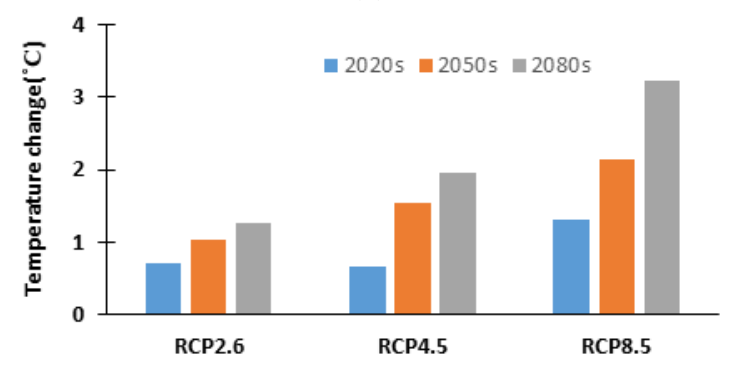

(b)

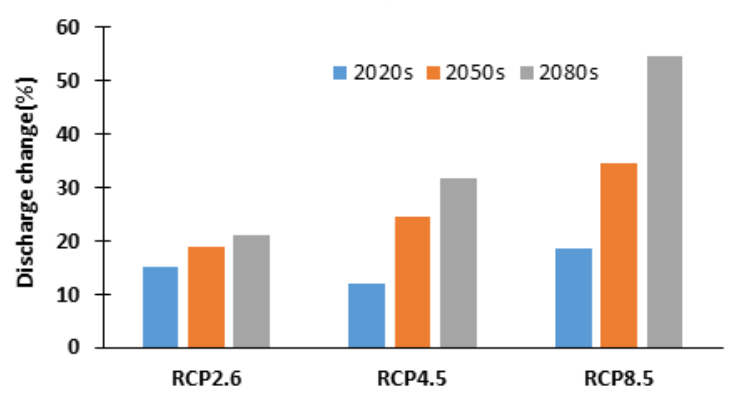

(c)

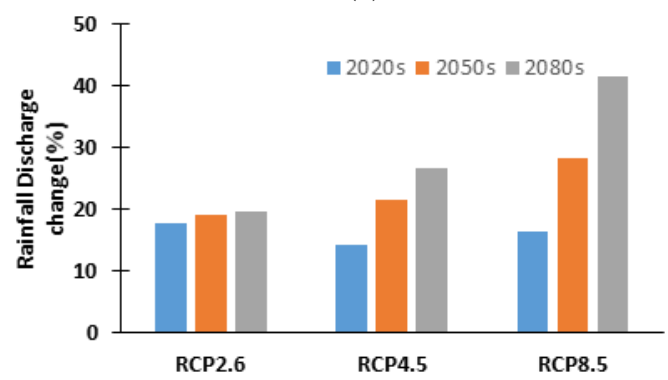

(d)

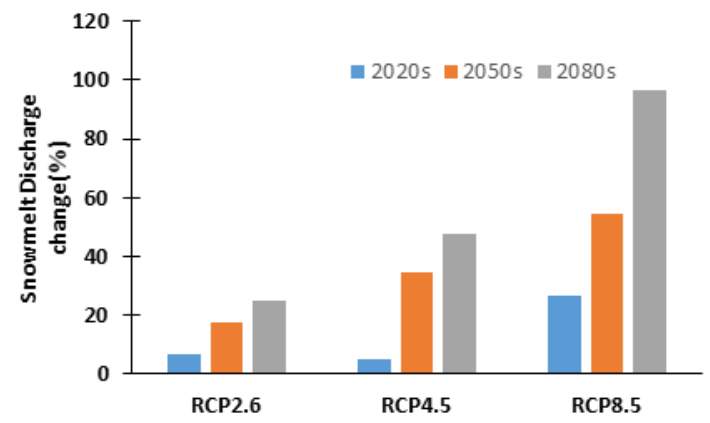

(e)

Fig. 13. a) $\%$ change in precipitation with the baseline period, b) Change in temperature $\left({ }^{\circ} \mathrm{C}\right)$ with the baseline period, c) $\%$ change in total discharge with the baseline period, d) $\%$ change in rainfall discharge with the baseline period, and e) \% change in snowmelt discharge with the baseline period. 


\section{International Journal of Engineering Applied Sciences and Technology, 2021 \\ Vol. 5, Issue 12, ISSN No. 2455-2143, Pages 10-22 \\ Published Online April 2021 in IJEAST (http://www.ijeast.com)}

The results show that the impacts of climate change on the snow-cover, ice reserves, and precipitation patterns have serious implications on the freshwater reserves and consequently on river flows. This snow-fed river is extremely sensitive to the changing precipitation and temperature patterns with time. The total discharge on the river including both rainfall and snowmelt discharge increase from the baseline period in all scenarios. RCP 2.6 has the lowest changes on the river discharge whereas RCP 8.5 has significant changes. In the 2080s under the RCP8.5 scenario, the discharge in the river will rise by about $55 \%$ with $42 \%$ due to rainfall and $97 \%$ due to snowmelt. Since few temperature rise generates considerable snowmelt discharge, e.g. about $0.3^{\circ} \mathrm{C}$ increase in temperature in RCP2.6 from 2020s to 2050s increases snowmelt discharge from $6.5 \%$ to $17.6 \%$, the temperature change has been seen more sensitive than that of precipitation in the mountain hydrology. If the climate change persists at the present rate, there is a potential risk of declining snow and ice reserves, and this rapid retreat will result in the creation and extension of moraine-dammed lakes and ice-dammed lakes, posing a potential peril in the downstream. Also, the combination of snowmelt and storms will cause heavy floods which create potential hazards on the ecosystem including both flora and fauna.

\section{CONCLUSION}

This study was carried out to estimate snowmelt contribution and the possible impacts of climate change in the data-scarce Himalayan River systems. For the study, the Dudhkoshi basin was selected. Snow-melt discharge was estimated by the conceptual Snowmelt Runoff Model (SRM) and climate change was studied by the Statistical Downscaling Model (SDSM). The snow area required to determine the snowmelt was calculated by delineating the snow in MODIS satellite images. This snow data along with hydrological and meteorological data were used as input in the model. Due to the lack of a sufficient number of snow and glacier stations in the Himalayas, one temperature and five precipitation stations were used to represent the whole basin.

For the hydrological simulation, calibration was carried out for the year 2011, and validation was carried out for the years 2012 and 2014. The coefficient of determination $\left(\mathrm{R}^{2}\right)$ and the volume difference $\left(D_{V}\right)$ showed that the model is well-calibrated and validated in this river basin. The annual average snowmelt contribution was found to $25 \%$ in this basin and it shows that the snow is a prominent source in the Himalayan river systems. For the climate change simulation, the CanESM2 model was used as a GCM model and the SDSM was used as a downscaling model. Calibration was carried out for the period 1961-1990, and validation was carried out for the period 19902005. The results showed that the SDSM model can replicate the precipitation and temperature well with some variability in both time and space. Climate change was studied for RCP2.6, RCP4.5, and RCP8.5 in the period 2011-2100, where 20112040, 2041-2070, and 2071-2100 were considered as 2020s, 2050s, and 2080s respectively. Both temperature and precipitation are likely to increase with time, having immense consequences at the end of the century. The northern part of the basin has huge snow and ice reserves and the increasing trend of temperature is going to pose higher threats to them. Also, the comparison of future discharges with the baseline period (1985-2009) showed a consistent increase, the maximum value being predicted in the long term towards the end of the century.

\section{REFERENCES}

Arora, V.K., and Boer, G.J. (2014). Terrestrial ecosystems response to future changes in climate and atmospheric CO2 concentration. Biogeosciences, (pp.4157-4171).

Bajracharaya, S.R., and Shrestha, B. (2011). The status of glaciers in the Hindu Kush-Himalayan region. Kathmandu, ICIMOD.

Bhattarai, B. C. (2011). Impact of Climate Change on Water Resources in view of Contribution of Snowmelt in Stream Flow: A case study from Langtang Basin. Kathmandu, Nepal.

Chhetri, R. B. (2015). Contribution of Snow and Glacier in Hydropower Potential and its Response to Climate Change: A Case Study of Koshi and Mahakali Basin of Nepal. Kathmandu: Department of Civil Engineering, Pulchowk Campus, MSc Thesis.

Christopher, A., S., Fan, Z., Mukherji, A., Immerzeel, W., Mustafa, D., and Bharati, L. (2019). Water in the Hindu Kush Himalaya. Kathmandu, ICIMOD.

Chylek, P., Li, J., Dubey M.K., Wang, M., and Lesins, G. (2011). Observed and model-simulated 20th century Arctic temperature variability: Canadian Earth System Model CanESM2. Atmospheric Chemistry and Physics Discussions, (pp.22893-22907).

Feng, S., Hu, Q., Hung, W., Ho, C.H., Li, R., and Tang, Z (2014). Projected climate regime shift under future global warming from multi-model, multi-scenario CIMP5 simulations. Global and Planetary Change, (pp.41-52).

Hall, D. K., V V. Salomonson and G. A. Riggs (2006). MODIS/Terra snow cover 8-Day L3 global $500 \mathrm{~m}$ grid. Version 5. Boulder, Colorado, USA, National Snow and Ice Data Centre.

Hall, D.K., Riggs, G.A., Salomonson, V.V., DiGirolamo, N.E., and Bayr, K.J. (2002). MODIS snow cover products, Remote sensing of Environment, (pp.181-194).

Heavens, N.G., Ward, D.S., and Mahowald, N.M. (2013). Studying and Projecting Climate Change with Earth System Models, Nature Education Knowledge.

IPCC (2008). A report of the Intergovernmental Panel on Climate change, Synthesis Report.

IPCC (2013a). The Physical Science Basis. Contribution of Working Group I to the Fifth Assessment Report of 


\section{International Journal of Engineering Applied Sciences and Technology, 2021 \\ Vol. 5, Issue 12, ISSN No. 2455-2143, Pages 10-22 \\ Published Online April 2021 in IJEAST (http://www.ijeast.com)}

the Intergovernmental Panel on Climate Change, Cambridge University Press, Cambridge.

Kang, R.B. (2005). Distributed snowmelt modeling with GIS and CASC2D at California Gulch, Colorado, Colorado State University.

Kattel, D. B., et al. (2012). Temperature lapse rate in complex mountain terrain on the southern slope of the central Himalayas, Thero Appl Climatol.

Khadka, A., L. P. Devokota and R. B. Kayastha. (2015). Impact of Climate Change on the Snow Hydrology of Koshi River Basin, Journal of Hydrology and Meteorology, Vol. 9, No. (pp.28-44).

Krishnan, R., Shrestha, A. B., Ren, G., Rajbhandari, R., Saeed, S., Sanjay, J., Syed, M. A., Vellore R., Xu, Y., You, Q., Ren, Y., Dimri, A. P., Lutz, A., Singh, P., Sun, X., and Zhan. (2019). Unraveling Climate Change in the Hindu Kush Himalaya: Rapid Warming in the Mountainous and Increasing Extremes. Katmandu, ICIMOD.

M., Molla. (2020). Statically Downscaling using different Representative Concentration Pass Ways of Emission Scenario; in the Case Wolikite, South West Ethiopia, International Journal of Environment Sciences \& Natural Resources.

Ma, Y., Huang, Y., Chen, X., Li, Y., and Bao, A. (2013). Modelling Snowmelt Runoff under Climate Change Scenarios in an Ungauged Mountainous Watershed, Northwest China, Mathematical Problems in Engineering.

Martinec, J. (1960). The degree-day factor for snowmelt runoff forecasting, IUGG General Assembly of Helsinki, IAHS Publ. No.51, (pp.468-477).

Martinec, J., A. Rango and R. T. Roberts. (2008). Snowmelt Runoff Model (SRM) User's Manual. New Mexico, New Mexico State University Press.

Martinec. J., A. Rango, and R. Roberts. (1994). The Snowmelt Runoff Model (SRM) User's Manual, Department of Geography, Univ. of Berne. Berne, Switzerland.

Mool, P. K., S. R. Bajrachaya, and B. R. Shrestha. (2001). Inventory of Glaciers, Glacial Lakes and Glacial Lake Outburst Floods, ICIMOD.

Nepal, S., et al. (2015). Comparative performance of GR4JSG and J2000 hydrological models in the Dudh Koshi catchment of the Himalayan region, International Congress on Modelling and Simulation, (pp.23952401).

Panday, P. and Brown, M. E. (2010). Snowmelt runoff modeling in the Tamor River Basinin the eastern Nepalese Himalaya. ResearchGate.

Pokhrel, B. K., et al. (2014). Comparison of two snowmelt modelling approaches in the DudhKoshi Basin, Hydrological Sciences Journal, 59:8, (pp.1507-1518).

Rao, P., G. Areendram, and R. Saren. (2008). Potential Impacts of Climate Change in Uttarakhand Himalayas, Mountain Forum Bulletin, (pp.28-29).
Sharma, T.P.P., Zhang, J., Khanal, N.R., Prodhan, F.A., Paudel, B., SHi, L. and Nepal, N. (2020). Assimilation of Snowmelt Runoff Model (SRM) using Satellite Remote Sensing Data in Budhi Gandaki River Basin, Nepal, Remote Sens, (pp.1951)

Tahir, A.A., Chevallier, P., Arnaud, Y., Neppel, L., and Ahmad, B. (2011). Modeling snowmelt-runoff under climate scenarios in the Hunza River basin, Karakoram Range, North Pakistan, J Hydrol, 409 (12), (pp.104-117)

Taylor, K.E., Stouffer, R.J., and Meehl, G.A (2012). An overview of CIMP5 and the experiment design, Bulletin of the American Meteorological Society, 93(4), (pp.485-498).

Wilby, R.L. and Dawson, C.W. (2007). SDSM 4.2- A decision support tool for the assessment of regional climate change impacts, User Manual, Lancaster/Environment Agency of England and Wales.

WMO (1986). Intercomparison of Models of Snowmelt Runoff, Operational Hydrol Geneva, Switzerland. 